\title{
OS CONCÍLIOS ECUMÊNICOS (III).
}

\author{
(Continuação). \\ IX CONCILIO ECUMENICO. \\ I CONCILIO DE LATRÃO.
}

Os oito concílios que a Igreja Católica reconhece com vaJidade ecumênica foram convocados pelos imperadores romaros do Oriente, percebendo-se a interferência laica no campo do poder espiritual.

Até o I Concílio de Latrão, IX Concílio Ecumênico, não bouve nenhuma tentativa de se realizar um concílio universal, excetuando-se o anti-Concílio que Carlos Magno quisera opor como um concílio do Império do Ocidente ao Concílio de Nicéia de 787 (VII Concílio Ecumênico, o segundo realizado em Nicéia).

O Concílio de Sutri, no qual o rei Henrique III (83) em 1406, afastando três papas que se opuseram às suas programações políticas, acabou com a ação do Papado devido as intrigas internas romanas, abrindo assim a porta para os movimentos reformistas em Roma.

Os concílios gerais papais da Alta Idade Média, convocados pelos papas da época da Reforma (são assim chamados pela própria Igreja) não são considerados como tendo validade ecumênica.

Assim, há um hiato na história da Igreja, que vai do VIII Concílio (o quarto realizado em Constantinopla no período de 5. de outubro de 869 a 28 de fevereiro de 870 ) ao IX Concílio (o primeiro realizado em Latrão, de 18 de março a 6 de abril de 1123), em que sucedem fatos de grande importância, quer para a História da Humanidade, quer para a da Igreja, tais como:

(89).. - Henrique III, o Negro, imperador da Alemanha de 1039 a 1056 fêz reconhecer a supremacia a os rels da Boêmia e da Hungria. Recebeu de seu pai Conrado II os territorios da Baviera, Suábia e Carintia. Nas lutas que teve com a Santa Sé, afastou três papas, dentre êles Gregório VI, o qual acusara de haver obtido o papado por simonia, porém na realidade obedecia alvos políticos. 
a). - Decretais Isidorianas do século IX;

b). - Sínodos de Pádua e Rheims em 1049;

c) . - Concílio de Roma em 1050;

d). - Sínodo de Roma em 1059, no qual o Papa Nicolau II promulgou o Decreto que reserva aos cardeais o direito de eleger o Papa;

e). - os Sínodos realizados por Gregório VII, que lutavam contra a Simonia, a Investidura pelos laicos. e pelo Celibato dos sacerdotes.

Os poderes espiritual e temporal, segundo Gregório VII, deveriam estar representados nos sínodos, sob a presidência. do Papa. A luta contra Henrique IV, Imperador da Alema-. nha, na Questão das Investiduras, terminou quando o mesmo. humilhou-se em Canossa em 1077.

Neste período, a Igreja, ora ganha, ora perde terreno, até quando o Papa Urbano II toma posição e inicia a pregação. da tarefa de libertar a Igreja Oriental dos domínios dos infiéis; as atenções voltam-se então para a primeira Cruzada, pregada por Pedro, o Eremita e decidida no Concílio de Clermont em 1095 (também não ecumênico).

"Apoiado numa verdadeira onda de entusiasmo, o Papado firmou sua posição eclesiástica e política na luta que. ainda não se tinha decidido pela liberdade da Igreja e. contra a supremacia do poder laico" (84).

$E^{\prime}$ bem possível que êstes 253 anos de intervalo sem concílios, tenham favorecido a autoridade papal e também tenham. tornado os bispos mais cônscios de seu importante papel, uma vez que as decisões eclesiásticas dependeriam de sua colaboração.

O problema das Investiduras segue paralelo às Cruzadas. O Papa Pascoal II (1099-1118) dá em 1111 ao rei Henrique V o direito da Investidura dos prelados do Império alemão pe-lo Tratado do Ponto Mammolo, que Gregório VII havia negado.

No ano seguinte, o Papado, viu-se obrigado a retirá-lo. no Concílio de Latrão de 1112, tais foram os protestos dos bispos, especialmente os franceses que chamaram-no de PrivilègeHonteux.

Por mais de 10 anos a Guerra das Investiduras será problema para Santa Sé; sòmente sob o pontificado de Calixto II, pela conhecida Concordata de Worms, foi que o imperador germânico renunciou ao bastão e ao anel.

(84). - Hubert Jedin, op. cit. 
Teremos então, para confirmar a Concordata de Worms, o I Concílio de Latrão, IX Ecumênico para a Igreja Católica. Entretanto, há historiadores especialistas em História da Igreja, que o consideram como o XI Concílio Ecumênico.

Foi êle convocado por Calixto II, na igreja episcopal do Papa, para 18 de março de 1123 .

O número de participantes oscila entre 300 bispos para alguns autores e 997 para outros; dentre êles lembramos Pandolfo, quando biografou Calixto II, embora o número apresentado, seja soma dos bispos e dos abades.

Foram votados 25 cânones neste Concílio, dentre os quais destacamos:

a). - a proibição da Simonia;

b). - a observância da Trégua de Deus, já tratado anteriormente em Clermont;

c). - aos Cruzados foi garantida a indulgência das penas temporais do pecado e a defesa das suas famílias e dos seus bens;

d). - pena de excomunhão aos peregrinos (em virtude de saques e pilhagens praticados em Roma);

e). - a investidura aos cargos eclesiásticos;

f). - a canonização do Bispo Conrado de Constantinopla (falecido em 976 e festejado em 26 de novembro);

g) . - a obtenção do pallium para o arcebispo Adalberto de Hamburgo-Bremen;

h). - a suspensão da luta pela precedência (85) entre os arcebispos de Cantuária e de York.

Seu encerramento deu-se sem as pompas bizantinas a 6 de abril de 1123 .

\section{CONCÍLIO ECUMENICO - II DE LATRÃO.}

Vai motivar o II Concílio de Latrão o que a Santa Sé chamou de "Cisma de Anacleto II" (86).

(85). - Essa precedência é conservada até hoje, Canterbury, York, Londres, etc., pág. 2.198, in Burke's Peerage Baronetage Knightage, issue 1949, Londres.

(86). - Anacleto II. Antipapa, neto de um judeu convertido, monje de Cluny; foi nomeado cardeal por Calixto II e legado na França. Usurpou o trono pontifício de 1130 a 1138 com o apôio de Rogério II, rei da Sicilia, obrigando Inocéncio II a sair de Roma; mas a Cristandade o abandonou e os concilios de Rheims e Ĺatrão o condenaram. 
Após a morte do Papa Honório II, que ocupou o Trono de São Pedro de 1124 a 1130, dezesseis cardeais elegeram Inocêncio II, que na vida profana chamou-se Gregório Papareschi.

Mal Inocêncio II é eleito, vinte cardeais elegem Pietro Pierleoni, de ascendência judaica, "o Papa vindo do Gheto", com o nome de Anacleto II, o qual foi muito prestigiado, por questões políticas, pelo rei Rogério II da Sicília.

Inocêncio II contou com o apôio de Bernardo de Claraval (Clairvaux) (87) e nas lutas internas da Igreja, foi apoiado por Lotário III.

Lotário III por duas vêzes marchou sôbre Roma, numa delas Inocêncio II colocou sôbre sua cabeça a corôa imperial.

Nessa época Lotário impôs sua autoridade aos soberanos eslavos do Báltico, submeteu as cidades lombardas e desalojou da Baixa Itália Rogério da Sicília (protetor do antipapa Anacleto II) e morreu no Tirol quando voltava à sua pátria.

Entretanto, Anacleto II até morrer não abandonou o Vaticano, o que ocorreu em 25 de janeiro de 1138 .

Mortos Lotário, que protegia o Pontífice e seu rival Anacleto II, Inocêncio II é reconhecido como Papa universalmente e convoca os bispos e abades do Oriente para um Sínodo Geral a realizar-se em Latrão em 4 de abril de 1139 .

O número de participantes oscila entre 500 (segundo os anais de Melk) e 10,00, segundo o relatório de Otto de Freising.

Sabemos que os participantes vieram de Lincolnshire na Inglaterra, Huesca na Espanha, de Jerusalém, França, Suíça, Alemanha e Austria, muito embora o único documento que chegou até nossos dias seja o da província eclesiástica de Compostela.

Inocêncio II akriu o Concílio lamentando a luta existente no seio da Igreja criada pelo cisma de Anacleto.

Enèrgicamente depôs os partidários do antipapa, os quais restituiram seus anéis, báculos e pálios episcopais, símbolos que os identificavam como príncipes da Igreja.

Foram votados 30 cânones, nos quais se tratou da Reforma Gregoriana, proibiu-se a usura (especialmente os onzená-

(87). - Bernardo de Claraval (Clairvaux) nasceu em 1090 perto de Diron, na França. Cêdo ingressou na vida monástica em Citeaux. Transferiu-se depois para Clatrvaux na Champagne. Em 1130 adquiriu merecida fama pela defesa que fêz da legitimidade da eleição de Inocêncio II, contra as pretençōes do antipapa Anacleto. Fêz através do Concilio de Estampes em 1131 que Luís VI da França, Henrique I da Inglaterra e Lotário da Alemanha, reconhecessem Inocêncio II como verdadeiro Papa. Reformou a Ordem de Cister, criando Bernardos e Bernardinas. 
rios, isto é, os que emprestavam dinheiro a 11\%), os torneios, o estudo do direito laico e de medicina por parte dos monges. Declararam não válidos os matrimônios contraídos pelos clérigos e monges e não só ilícitos como o foram anteriormente.

Os Cabidos, que vão ter grande fôrça política e administrativa na Idade Média, não foram esquecidos entre os cânones, muito pelo contrário, são confirmados os direitos a eleição dos bispos.

Dentre os cânones, encontramos a excomunhão para os que rejeitassem a eucaristia, o batismo das crianças, o sacerdócio e o casamento.

Em 18 de abril foi canonizado o monje beneditino Estúrmio de Fulda, o qual contribuiu para a evangelização dos saxões. Suas relíquias são conservadas com as de São Bonifácio, de quem foi discípulo em Fulda, e é comemorado em 17 de dezembro.

O Concílio foi encerrado em 30 de abril de 1139, sem dêle ter tomado parte Bernardo de Clairvaux, o qual pregou a realização da segunda Cruzada, comandada por Conrado III da Alemanha (1147-1149) e Luís VII, de França, cujo resultado desastroso conhecemos.

\section{CONCILIO ECUMENICO - III DE LATRÃO.}

Vamos ter como motivo do III Concílio de Latrão, o que já dera origem aos dois primeiros - política eclesiástica e a luta das investiduras (88).

"A eleição de Roland Bandinelli de Sena para Papa (Alexandre III, 1159-1181), opôs o imperador Frederico I. apelidado o Barbaruiva, sob a pressão da representação brusca dos cardeais reunidos na Dieta de Besançon em 1157, um contra candidato na pessoa do Cardeal Otaviano de Montecelio (Vitor IV). A tentativa levada a efeito por Barbaruiva, para restituir a soberania do Império da Itália, levou as cidades da Itália do Norte, para o lado de Alexandre III, que se recusou a comparecer ao Concílio reunido em Pádua em 1160 . Só depois de uma en-

(88). - Querela ou guerra das Investiduras, luta entre Papas e os imperadores da Alemanha, a respeito da distribuiçáo e investiduras de títulos eclesí́sticos, de 1077 a 1122 . Foi particuiarmente viva nos reinados do p\&pa Gregório VII e do Imperador Henrique IV e acabou pelo princípio da separação dos dols poderes, ficando a investidura temporal pertencendo s6 ao rel e a investidura espiritual ao Papa. 
carniçada luta, que durou cêrca de 15 anos, Barbaruiva abandonou, na Paz de Veneza (1177), seu antipapa - que fôra Calixto III, o segundo sucessor de Vitor - e restituiu os benefícios por êle ocupados. O III Concílio de Latrão, previsto já nas atas da $\mathrm{Paz}$, foi o sêlo eclesiástico pôsto sôbre a conclusão da paz, que fortaleceu o poder do Papado. Ao Concílio, segundo as palavras da convocação enviada aos bispos de Toscana, Calábria, "conforme os costumes dos Santos Padres", confirma a paz e empresta-lhe a fôrça que, sem isso, ela não teria. Portanto, Alexandre liga o Concilio aos da Antiga Igreja. Seu desêjo era reunir "todo o mundo católico, pelo menos o mundo eclesiástico" (89).

E' bem possível que Frederico Barbaruiva quando tentou a soberania do Império na Itália, estivesse preocupado, não com o problema eclesiástico, porém com a política bizantina, que não era em nada favorável ao Império latino; pelo menos é o que nos leva a crer Ostrogorsky (90).

"Malgré les succés remportés dans l'Orient latin et en Hongrie, l'empire byzantin se trouvait de plus en plus isolé, et vers la fin des années 70, la position de Manuel se mit à branler de toutes parts. Les espoirs placés dans une collaboration avec Rome s'avérèrent trompeurs: les conditions requises pour une union des Églises faisaient défaut des deux côtés et partout - à Venise, en Dalmatie, en Hongrie - c'était le parti de la curie qui travaillait contre l'empereur byzantin. Infatigable dans la recherche des voies et moyens, Manuel appuya d'importants subsides la ligue des villes lombardes en lutte contre Frédéric Barberousse. Mais ces armes même lui furent enlevées par le traité de Venise (1177), qui mit fin à la guerre avec la ligue lombarde et amena une réconciliation du pape avec Frédéric Ier. Après la consommation du schisme occidental que Manuel avait su exploiter avec une grande habilité, les dernières conditions d'une collaboration du pape avec Byzance avaient disparu. Manuel voyait dans tout ennemi de Barberousse un ami; Barbarousse, de son côté, recherchait l'alliance des adversaires de l'empereur byzantin. Depuis 1173 il était en relations avec le sultan d'Iconium, Kilidj Arslan".

Dêsse Concílio, o terceiro realizado em Latrão, chegou até nós a lista de seus participantes episcopais num total de 291 nomes.

(89). - Hubert Jedín, op. cit., págs. 56-57.

(90). - Ostrogorsky, op. cit., pág. 412. 
Sua maioria era constituída de bispos chegados da Itália, quer da parte central, quer da parte meridional, bem como da Grã-Bretanha, Escócia, Irlanda, Alemanha, França, Espanha e Dalmácia; os imperadores, reis e príncipes cristãos, enviaram também seus representantes ao Concílio.

Bem pouco sabemos a respeito das decorrências conciliares, pois o Concílio só realizou nas seguintes datas 5,7 ou 14 e 19 ou 22 de março de 1197, que foi a de encerramento.

Guilherme, Ascebispo de Tiro (1130-1184), relata em sua História das Cruzadas o seguinte:

"Sôbre as resoluções dêste Concilio, os nomes, o número e o título dos bispos, leia-se o relatório que redigimos a pedido dos sinodais e que depositamos no arquivo da nossa igreja de Tirus".

Esse documento, entretanto, não chegou até nós, porém o resultado do Concílio, 27 foram consignados em cânones.

Versavam êles sôbre a necessidade de dois terços para a eleição papal, a anulação da dignidade e a sagração dos cismáticos.

Foi regulado que para a eleição do bispo seria exigida a idade mínima de 30 anos (esta exigência vigora até hoje) e a legitimidade da sua ancendência. Foi proibida a acumulação de benefícios. As Catedrais deveriam possuir professor para ensinar aos clérigos e as primeiras letras às crianças pobres. Vemos, por aí como preocupou-se o Concílio com o ensino laico dos pobres, pois na época poucas pessoas tinham a oportunidade de aprender.

O Concílio deu grande realce, prometendo punir com excomunhão todo aquêle que fornecesse armas ou materiais para armamento (ferro e madeira de construção de navios) aos sarracenos. Foi proibido aos sarracenos e judeus terem escravos cristãos. Foram anematizados os cátaros (91) espalhados no sul da França, o anátema atingia a quem os hospedassem ou simplesmente com êles negociassem: seus bens deveriam ser confiscados. Quem a conselho dos bispos lutassem contra êles,

(91). - Cátaroś (também chamados puros) afirmavam a existência de um duplo princípio universal, bom o uno, crlador do mundo invisivel e espiritual e autor, o segundo, do mundo da matéria. Rechaçavam os sacramentos e negavam as fôrças do juramento; atacavam a Igreja e ao Egtado, negando a ambos o poder de inflingir castigos. Procedia a seita das comarcas búlgaras e se estenderam muito nos séculos XI e XIII principalmente no Sul da França. Foram aniquilados com seus semelhantes, os valdenses, na cruzada contra os albigenses. 
estaria sob a proteção da Igreja, em pé de igualdade com os Cruzados.

Percebe-se nìtidamente que a Igreja está com fôrça, quer no domínio eclesiástico, quer no laico.

A aplicação de castigo contra os herejes na Idade Média é bastante diferente da Igreja Antiga, pois a heresia passa a ser considerada não mais como um êrro na fé, vai muito mais além, mas sim como um atentado contra a Igreja e a sociedade, condenando a doutrina e exterminando seu criador.

Tôda essa conjuntura é um esbôço para a futura página histórica da Igreja, que foi chamada de Santa Inquisição. A Igreja dia a dia, foi aos poucos trazendo para seu seio o cetro do mando, em detrimento dos próprios imperadores. Ela manda e desmanda.

Assim, os três primeiros Concílios de Latrão conseguiram reconhecimento universal pelo fato de terem colocado ponto final na Querela das Investiduras, nos cismas de Anacleto II e de Barbaruiva.

(Continua). 